\title{
Effect of the type and method of additives on the productivity of mushrooms grown in industrial conditions
}

\author{
Ekaterina G. Alexandrova ${ }^{1, *}$, Tatyana $G$. Lazareva $^{2}$ \\ ${ }^{1}$ Department of Production Technology and Expertise of Products from Plant Raw Materials, Samara State Agrarian University, \\ Samara, 446442, Russia \\ ${ }^{2}$ Department of Accounting and Statistics, Samara State Agrarian University, Samara, 446442, Russia
}

\begin{abstract}
The paper summarizes and analyzes the results of practical studies on the cultivation of Agaricus bisporus champignon mushrooms on a synthetic substrate with the introduction of organic additives into it food and processing wastes: brewing waste, soybean and sunflower meal semolina. A yield analysis was carried out; indicators characterizing the quality of Agaricus bisporus mushrooms were studied; dependence of yield and quality of mushrooms on flush was demonstrated. It was noted that the preparation time of the substrate affects the number of flushes, respectively, and, correspondingly, on the yield of mushrooms: when growing mushrooms on a synthetic substrate prepared in the spring-summer period, two flushes are noted and, as a result, a higher yield is noted compared to mushrooms grown on a substrate prepared in the autumn-winter period. The study of the quality of fruit bodies showed that the use of additives increased the content of protein, fiber, fat and ash elements (potassium, phosphorus, calcium, sodium and magnesium). The results showed that the brewing waste is the best organic additive, which contributes not only to the growth of yield, but also to the improvement of the quality of cultured mushrooms. The study demonstrated that the quality of mushrooms obtained in the first flush exceeds the qualitative indicators of mushrooms grown in the second flush. The authors concluded that it is advisable to use organic waste (brewing waste, sunflower meal) as a substrate element when growing mushrooms in industrial conditions.
\end{abstract}

\section{Introduction}

The issues of recycling by-products and production waste are relevant for almost all enterprises. Agroindustrial enterprises are not an exception. For example, crop producers experience a problem in the disposal of straw, livestock and poultry manure and litter. The wastes of alcohol and brewing production are significant in volume and amount to about 10 million tons per year, while only a tenth of them will be processed. The main volume of brewing by-products, up to $85 \%$, accounts for spent grain - brewing waste. Many brewing enterprises try to avoid waste disposal by transferring the entire volume of by-products for secondary use, including for agriculture $[1,2]$. The search for directions of secondary use of waste from food and processing industries and maximizing the economic effect of such use predetermined the main directions of research.

The industrial production of mushrooms in Russia is dynamically developing, which is supported by the state's interest in the development of this sub-sector, high demand of the population for mushroom products, possibility of its year-round production [3-5]. The studies showed that the availability of compost raw materials, the use of intensive technologies aimed at reducing the substrate growing time and the removal of fruit bodies are the main reserves of growth in mushroom production $[6,7]$. As a rule, the wastes of agriculture, processing of agricultural raw materials and the food industry contain an organic (free) substance with great raw material value, therefore, the issues of harmonizing the methods of their full utilization in the conditions of the technological process of cultivation of mushrooms on an industrial basis are particularly relevant.

The purpose of this study is to analyze the effect of the type and method of applying organic additives (production waste) on the yield and quality of mushrooms grown in industrial conditions.

\section{Materials and methods}

The influence of the type and method of applying additives in the cultivation of mushrooms was studied in the university laboratories of the Department of Production Technology and Expertise of Products from Plant Raw Materials of the Faculty of Technology of Samara State University. The factor model of experiments is shown in Figure 1.

\footnotetext{
* Corresponding author: fegtgf@mail.ru
} 


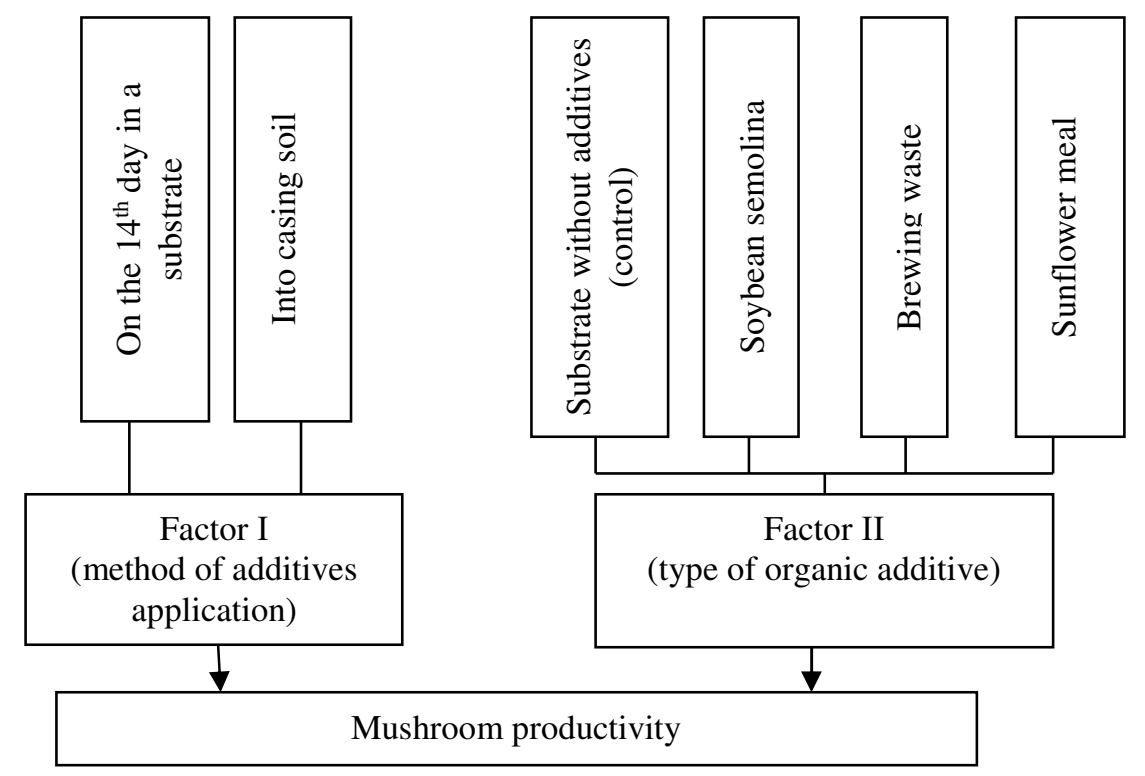

Fig. 1. Experimental scheme to assess the degree of influence of the type and method of additives application in the cultivation of mushrooms (Agaricus bisporus) on their productivity.

The conditions and features of the experiments corresponded to the following technological parameters: cultured mushroom - Agaricus bisporus A-15 (white); replication of experiments - quadruple; spawning rate $5 \%$ of raw substrate weight; substrate composition $50 \%$ wheat straw, $50 \%$ bird droppings, gypsum at a rate of $60 \mathrm{~kg}$ per 1 ton of prepared substrate; substrate preparation period - winter (February-March), summer (August-September); substrate height $-15 \mathrm{~cm}$; substrate manufacturer - Orix LLC; nitrogen content in a substrate on a dry basis - from 2.1 to $2.4 \%$ organic, not more than $0.02 \%$ ammonium; active acidity $(\mathrm{pH})$ - from 6.7 to 7.4 .

\section{Results}

Earlier studies prove that the period of fruiting and yield of Agaricus bisporus mushrooms directly depends on the time of substrate preparation - in a substrate prepared in winter, the main yield of mushrooms was recorded at the first flush, while on a substrate prepared in summer the yield of products and yield of the first two flushes were at a fairly high level $[8,9]$.

The data given in Table 1 show that the addition of the studied organic additives (soybean semolina, brewing waste, sunflower meal) by various methods (in the casing soil, on the $14^{\text {th }}$ day in a substrate) significantly increased the yield of mushrooms.

The studied terms and methods of applying soybean semolina had a positive effect on the yield of Agaricus bisporus mushrooms and, on average, increased the yield of mushrooms compared to the control version by 69 $71 \%$.

As shown by the experimental data systematized in Table 2, the introduction of all kinds of organic additives has increased the yield of mushrooms.

In the process of analyzing yields from the flushes of mushrooms grown on a substrate prepared in summer it was noted that most of the crop - about $2 / 3$ falls on the $1^{\text {st }}$ flush.

The yield of Agaricus bisporus mushrooms grown on a substrate without the use of additives was $7.71 \mathrm{~kg} / \mathrm{m}^{2}$, which is the minimum value under the conditions of the experiment.

The brewing waste has the most effect on the yield, and its introduction into the casing soil is more effective than on the $14^{\text {th }}$ day in a substrate. When the brewing waste was introduced on the $14^{\text {th }}$ day in a substrate, the yield of mushrooms for both flushes was $16.04 \mathrm{~kg} / \mathrm{m}^{2}$, while when it was introduced into the casing soil it was $3.06 \mathrm{~kg} / \mathrm{m}^{2}$ more.

The introduction of soybean semolina showed relatively good results, just as in the previous version it is preferable to add it to the casing soil $-16.55 \mathrm{~kg} / \mathrm{m}^{2}$ of mushrooms were collected for both flushes.

The addition of sunflower meal gave the lowest yield compared to organic additives. According to this version of the experiment, the maximum yield was obtained when the additive was placed in a casing soil -16.18 $\mathrm{kg} / \mathrm{m}^{2}$, while on the $14^{\text {th }}$ day in a substrate $-1.19 \mathrm{~kg} / \mathrm{m}^{2}$ less.

Thus, the largest collection of mushrooms when grown on a substrate prepared in summer over two flushes may be stimulated by using the brewing waste as an organic additive and introducing it into the casing soil.

Organic additives are characterized by their high content of easily digestible nutrients, and therefore may serve as an additional source of "saturation" of a substrate and, accordingly, fruit bodies $[10,11]$.

Table 3 systematizes data on the effect of the type and method of applying organic additives on the chemical composition of fruit bodies of Agaricus bisporus.

The crude protein content of the fruit body of champignons cultivated without organic additives was on average $28.82 \%$ per absolute dry matter (Table 3 ). 
Table 1. Yield of Agaricus bisporus mushrooms grown on a synthetic substrate prepared in winter, $\mathrm{kg} / \mathrm{m}^{2}$.

\begin{tabular}{|l|c|c|c|}
\hline \multirow{2}{*}{\multicolumn{2}{|c|}{ Type of organic additive }} & \multicolumn{3}{|c|}{ Terms and methods of application } \\
\cline { 2 - 4 } & in a substrate & on the $14^{\text {th }}$ day in a substrate & in the casing soil \\
\hline Without additives (control) & 5.77 & - & - \\
\hline Soybean semolina & - & 9.86 & 9.74 \\
\hline Brewing waste & - & 10.75 & 11.21 \\
\hline Sunflower meal & - & 9.86 & 11.27 \\
\hline
\end{tabular}

Table 2. Yield of Agaricus bisporus mushrooms grown on a synthetic substrate prepared in summer, $\mathrm{kg} / \mathrm{m}^{2}$.

\begin{tabular}{|l|l|c|c|c|}
\hline \multirow{3}{*}{$\begin{array}{c}\text { Type of organic } \\
\text { additive }\end{array}$} & \multicolumn{1}{|c|}{ Flush } & \multicolumn{3}{c|}{ Terms and methods of application } \\
\cline { 3 - 5 } & & in a substrate & $\begin{array}{c}\text { on the } 14^{\text {th }} \\
\text { day in a } \\
\text { substrate }\end{array}$ & $\begin{array}{c}\text { in the casing } \\
\text { soil }\end{array}$ \\
\hline \multirow{2}{*}{$\begin{array}{c}\text { Without additives } \\
\text { (control) }\end{array}$} & $1^{\text {st }}$ flush & 5.36 & - & - \\
\cline { 2 - 5 } & $2^{\text {nd }}$ flush & 2.35 & - & - \\
\cline { 2 - 5 } & Total & 7.71 & - & - \\
\hline Soybean semolina & $1^{\text {st }}$ flush & - & 10.31 & 11.35 \\
\cline { 2 - 5 } & $2^{\text {nd }}$ flush & - & 4.67 & 5.20 \\
\cline { 2 - 5 } & Total & - & 14.98 & 16.55 \\
\hline \multirow{3}{*}{ Brewing waste } & $1^{\text {st }}$ flush & - & 10.96 & 12.53 \\
\cline { 2 - 5 } & $2^{\text {nd }}$ flush & - & 5.08 & 6.57 \\
\cline { 2 - 5 } & Total & - & 16.04 & 19.10 \\
\hline \multirow{3}{*}{ Sunflower meal } & $1^{\text {st }}$ flush & - & 4.58 & 11.22 \\
\cline { 2 - 5 } & $2^{\text {nd }}$ flush & - & 14.99 & 16.18 \\
\cline { 2 - 5 } & Total & & \\
\hline
\end{tabular}

Table 3. Chemical composition of mushrooms grown on a synthetic substrate prepared in winter, $\%$ absolute dry matter

\begin{tabular}{|c|c|c|c|c|c|}
\hline \multirow{2}{*}{$\begin{array}{c}\text { Type of organic } \\
\text { additive }\end{array}$} & \multirow{2}{*}{$\begin{array}{l}\text { Terms and methods } \\
\text { of application }\end{array}$} & \multicolumn{4}{|c|}{ Chemical composition of mushroom fruit bodies } \\
\hline & & nitrogen & protein & fiber & fat \\
\hline $\begin{array}{l}\text { Without additives } \\
\text { (control) }\end{array}$ & 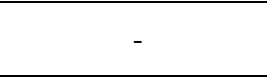 & 4.61 & 28.82 & 7.33 & 1.63 \\
\hline \multirow[t]{2}{*}{ Soybean semolina } & $\begin{array}{l}\text { on the } 14^{\text {th }} \text { day in a } \\
\text { substrate }\end{array}$ & 4.90 & 30.62 & 7.49 & 1.64 \\
\hline & in a casing soil & 4.92 & 30.75 & 7.41 & 1.73 \\
\hline \multirow{2}{*}{ Brewing waste } & $\begin{array}{l}\text { on the } 14^{\text {th }} \text { day in a } \\
\text { substrate }\end{array}$ & 4.96 & 30.98 & 8.45 & 1.44 \\
\hline & in a casing soil & 4.89 & 30.57 & 8.31 & 1.49 \\
\hline \multirow[t]{2}{*}{ Sunflower meal } & $\begin{array}{l}\text { on the } 14^{\text {th }} \text { day in a } \\
\text { substrate }\end{array}$ & 4.90 & 30.60 & 8.58 & 1.88 \\
\hline & in a casing soil & 4.90 & 30.62 & 7.98 & 1.81 \\
\hline
\end{tabular}

The use of organic additives had a positive effect and stimulated the increase in the amount of crude protein in the mushrooms from 6.2 to $7.5 \%$ compared to the value recorded in the control version.

The largest content of crude protein in the mushrooms was noted when introduced on the $14^{\text {th }}$ day into the brewing waste substrate and amounted to $30.98 \%$ per absolute dry matter.

The smallest fiber content is noted in mushrooms grown on a substrate without the use of organic additives, and the largest was observed in versions with the introduction of sunflower meal into a substrate on the $14^{\text {th }}$ day.

The largest content of crude fat in the dry matter of the fruit bodies of champignon was noted when they were grown on a substrate using sunflower meal according to the studied terms and methods of their application.

For all methods of brewing waste application, the content of crude fat in dry matter of mushrooms remains minimum within $1.44-1.49 \%$ per absolute dry matter.
The protein, fiber and fat content of Agaricus bisporus mushrooms collected from the substrate prepared during summer is greater than that of the mushrooms prepared during winter (Table 4).

The largest amount of crude protein was contained in the mushrooms of the first flush using the organic additive of the brewing waste by the studied methods and ranged from 31.14 to $31.29 \%$ per dry matter and the second flush - from 30.92 to $30.94 \%$ per dry matter. High crude protein content was observed in the dry matter of mushrooms obtained in all variants of the experiment using additives compared to the control.

High fat content was noted in mushrooms grown on a substrate using sunflower meal by all methods of its application, and the values obtained in mushrooms of the second flush exceed the values of the first flush by an average of $5 \%$.

The analysis of the chemical composition of mushrooms grown in the first flush on a substrate using organic additives showed that it exceeds the values (nitrogen and protein content) noted in the second flush, 
as well as similar values obtained in both flushes on a substrate sample without additives [12, 13].

The influence of organic additives on the level of mineral substances in mushrooms grown on a substrate prepared in winter was analyzed based on the data shown in Table 5.

Table 4. Chemical composition of Agaricus bisporus grown on a synthetic substrate prepared in summer, \% absolute dry matter

\begin{tabular}{|c|c|c|c|c|c|c|c|c|c|}
\hline \multirow{4}{*}{$\begin{array}{l}\text { Type of organic } \\
\text { additive }\end{array}$} & \multirow{4}{*}{$\begin{array}{l}\text { Terms and } \\
\text { methods of } \\
\text { application }\end{array}$} & \multicolumn{8}{|c|}{ Chemical composition of mushroom fruit bodies } \\
\hline & & \multicolumn{2}{|c|}{ nitrogen } & \multicolumn{2}{|c|}{ protein } & \multicolumn{2}{|c|}{ fiber } & \multicolumn{2}{|c|}{ fat } \\
\hline & & \multicolumn{8}{|c|}{ flush } \\
\hline & & 1 & 2 & 1 & 2 & 1 & 2 & 1 & 2 \\
\hline $\begin{array}{l}\text { Without additives } \\
\text { (control) }\end{array}$ & - & 4.74 & 4.78 & 29.58 & 29.86 & 7.20 & 7.26 & 1.65 & 1.60 \\
\hline \multirow{2}{*}{$\begin{array}{l}\text { Soybean } \\
\text { semolina }\end{array}$} & $\begin{array}{l}\text { on the } 14^{\text {th }} \\
\text { day in a } \\
\text { substrate }\end{array}$ & 4.87 & 4.79 & 30.43 & 29.93 & 7.92 & 7.64 & 1.63 & 1.57 \\
\hline & $\begin{array}{l}\text { in a casing } \\
\text { soil }\end{array}$ & 4.91 & 4.81 & 30.66 & 30.05 & 7.82 & 7.99 & 1.70 & 1.81 \\
\hline \multirow[t]{2}{*}{ Brewing waste } & $\begin{array}{l}\text { on the } 14^{\text {th }} \\
\text { day in a } \\
\text { substrate }\end{array}$ & 5.01 & 4.95 & 31.29 & 30.92 & 8.58 & 8.97 & 1.54 & 1.44 \\
\hline & $\begin{array}{l}\text { in a casing } \\
\text { soil }\end{array}$ & 4.98 & 4.95 & 31.14 & 30.94 & 8.26 & 8.78 & 1.37 & 1.50 \\
\hline \multirow[t]{2}{*}{ Sunflower meal } & $\begin{array}{l}\text { on the } 14^{\text {th }} \\
\text { day in a } \\
\text { substrate }\end{array}$ & 4.90 & 4.89 & 30.59 & 30.54 & 7.97 & 7.93 & 1.84 & 1.90 \\
\hline & $\begin{array}{l}\text { in a casing } \\
\text { soil }\end{array}$ & 4.87 & 4.87 & 30.43 & 30.45 & 7.67 & 8.29 & 1.74 & 1.86 \\
\hline
\end{tabular}

Table 5. Content of mineral substances in Agaricus bisporus grown on a synthetic substrate prepared in winter, \% absolute dry matter

\begin{tabular}{|c|c|c|c|c|c|c|c|}
\hline \multirow{2}{*}{$\begin{array}{c}\text { Type of organic } \\
\text { additive }\end{array}$} & \multirow{2}{*}{$\begin{array}{l}\text { Terms and } \\
\text { methods of } \\
\text { application }\end{array}$} & \multicolumn{6}{|c|}{ Mineral compposition of mushroom fruit bodies } \\
\hline & & Ash & $\begin{array}{l}\text { Potass } \\
\text { ium }\end{array}$ & $\begin{array}{l}\text { Phospho } \\
\text { rus }\end{array}$ & Calcium & $\begin{array}{l}\text { Magnesi } \\
\text { um }\end{array}$ & Sodium \\
\hline $\begin{array}{l}\text { Without } \\
\text { additives } \\
\text { (control) }\end{array}$ & - & 5.82 & 3.29 & 0.79 & 0.051 & 0.13 & 0.069 \\
\hline \multirow{2}{*}{$\begin{array}{l}\text { Soybean } \\
\text { semolina }\end{array}$} & $\begin{array}{l}\text { on the } 14^{\text {th }} \\
\text { day in a } \\
\text { substrate }\end{array}$ & 6.08 & 3.56 & 0.71 & 0.053 & 0.10 & 0.073 \\
\hline & $\begin{array}{l}\text { in a casing } \\
\text { soil }\end{array}$ & 5.89 & 3.31 & 0.76 & 0.060 & 0.13 & 0.061 \\
\hline \multirow[t]{2}{*}{ Brewing waste } & $\begin{array}{l}\text { on the } 14^{\text {th }} \\
\text { day in a } \\
\text { substrate }\end{array}$ & 6.34 & 3.66 & 0.78 & 0.057 & 0.13 & 0.073 \\
\hline & $\begin{array}{l}\text { in a casing } \\
\text { soil }\end{array}$ & 6.30 & 3.62 & 0.78 & 0.059 & 0.14 & 0.074 \\
\hline \multirow[t]{2}{*}{ Sunflower meal } & $\begin{array}{l}\text { on the } 14^{\text {th }} \\
\text { day in a } \\
\text { substrate }\end{array}$ & 5.93 & 3.35 & 0.72 & 0.057 & 0.13 & 0.071 \\
\hline & $\begin{array}{l}\text { in a casing } \\
\text { soil }\end{array}$ & 6.12 & 3.51 & 0.74 & 0.061 & 0.11 & 0.061 \\
\hline
\end{tabular}

The experimental data show that the addition of the studied organic additives to the substrate contributes to an increase in the level of ash, potassium and sodium (with the exception of the addition of soybean semolina and sunflower meal to the casing soil) in the dry matter of fruit bodies compared to the level of their content in fruit bodies grown in the control version.

High crude ash content (from $6.30 \%$ per absolute dry matter up to $6.34 \%$ per absolute dry matter) and potassium (from $3.62 \%$ per absolute dry matter up to $3.66 \%$ per absolute dry matter) are typical for mushrooms grown using a brewing waste, which is on average $8.6 \%$ and $10.6 \%$ higher than the levels recorded for reference mushrooms.

The amount of phosphorus decreases on average for all test samples to $0.75 \%$ per absolute dry matter.

The weight fraction of magnesium and sodium remains at almost the same level as without the use of additives.

In the mushrooms obtained on a substrate prepared in summer, the mineral content was significantly influenced not only by the kind of organic additive and the method of its application, but also by a certain relationship to the champignon flush (Table 6). 
Table 6. Content of mineral substances in Agaricus bisporus grown on synthetic substrate prepared in summer, \% absolute dry matter

\begin{tabular}{|c|c|c|c|c|c|c|c|c|}
\hline \multirow{2}{*}{$\begin{array}{l}\text { Type of } \\
\text { organic } \\
\text { additive }\end{array}$} & \multirow{2}{*}{$\begin{array}{l}\text { Terms and } \\
\text { methods of } \\
\text { application }\end{array}$} & \multirow[t]{2}{*}{ Flush } & \multicolumn{6}{|c|}{ Mineral compposition of mushroom fruit bodies } \\
\hline & & & Ash & $\begin{array}{l}\text { Potass } \\
\text { ium }\end{array}$ & $\begin{array}{l}\text { Phospho } \\
\text { rus }\end{array}$ & $\begin{array}{l}\text { Calciu } \\
\mathrm{m}\end{array}$ & $\begin{array}{l}\text { Magnesi } \\
\text { um }\end{array}$ & Sodium \\
\hline \multirow{2}{*}{$\begin{array}{l}\text { Without } \\
\text { additives } \\
\text { (control) }\end{array}$} & \multirow{2}{*}{ - } & 1 flush & 5.6 & 3.34 & 0.72 & 0.051 & 0.12 & 0.061 \\
\hline & & 2 flush & 5.8 & 3.42 & 0.62 & 0.041 & 0.07 & 0.046 \\
\hline \multirow{4}{*}{$\begin{array}{l}\text { Soybean } \\
\text { semolina }\end{array}$} & \multirow{2}{*}{$\begin{array}{l}\text { on the } 14^{\text {th }} \\
\text { day in a } \\
\text { substrate }\end{array}$} & 1 flush & 6.06 & 3.51 & 0.64 & 0.057 & 0.11 & 0.058 \\
\hline & & 2 flush & 5.86 & 3.54 & 0.62 & 0.041 & 0.07 & 0.048 \\
\hline & \multirow{2}{*}{$\begin{array}{l}\text { in a casing } \\
\text { soil }\end{array}$} & 1 flush & 5.72 & 3.26 & 0.63 & 0.057 & 0.12 & 0.060 \\
\hline & & 2 flush & 5.97 & 3.48 & 0.62 & 0.037 & 0.07 & 0.046 \\
\hline \multirow{4}{*}{$\begin{array}{l}\text { Brewing } \\
\text { waste }\end{array}$} & \multirow{2}{*}{$\begin{array}{l}\text { on the } 14^{\text {th }} \\
\text { day in a } \\
\text { substrate }\end{array}$} & 1 flush & 6.08 & 3.50 & 0.76 & 0.061 & 0.12 & 0.071 \\
\hline & & 2 flush & 6.34 & 3.72 & 0.71 & 0.045 & 0.08 & 0.058 \\
\hline & \multirow{2}{*}{$\begin{array}{l}\text { in a casing } \\
\text { soil }\end{array}$} & 1 flush & 6.43 & 3.62 & 0.79 & 0.059 & 0.14 & 0.069 \\
\hline & & 2 flush & 6.31 & 3.63 & 0.74 & 0.048 & 0.11 & 0.058 \\
\hline \multirow{4}{*}{$\begin{array}{l}\text { Sunflowe } \\
\text { r meal }\end{array}$} & \multirow{2}{*}{$\begin{array}{l}\text { on the } 14^{\text {th }} \\
\text { day in a } \\
\text { substrate }\end{array}$} & 1 flush & 5.85 & 3.51 & 0.63 & 0.055 & 0.12 & 0.059 \\
\hline & & 2 flush & 5.86 & 3.54 & 0.65 & 0.042 & 0.08 & 0.042 \\
\hline & \multirow{2}{*}{$\begin{array}{l}\text { in a casing } \\
\text { soil }\end{array}$} & 1 flush & 6.02 & 3.48 & 0.62 & 0.060 & 0.10 & 0.063 \\
\hline & & 2 flush & 5.81 & 3.50 & 0.63 & 0.041 & 0.08 & 0.044 \\
\hline
\end{tabular}

Table 6 makes it possible to conclude that compared to mushrooms of the second flush yield both in the control version and in samples using soybean semolina added to a substrate on the $14^{\text {th }}$ day, brewing waste into casing soil and sunflower meal into casing soil, the dry matter of mushrooms of the first flush contains more crude ash, phosphorus, calcium, magnesium and sodium, but, at the same time, they have lower potassium content.

The maximum content of crude ash in the dry matter of the fruit bodies of Agaricus bisporus grown on a substrate prepared in summer is observed in versions where brewing waste is used as an organic additive. Higher content of ash elements in mushrooms of the first and second flush using a brewing waste is caused by the fact that it contains more potassium, phosphorus, calcium, magnesium and sodium than other organic additives.

\section{Discussion}

The results of the experiment show that organic additives are effective in increasing yields and improving the quality of mushrooms grown on synthetic substrates used in industrial environments. It is noted that the number of flushes depends on the time of substrate preparation, which in turn affects the volume of production. Stimulation of yield growth is possible by using the test additives, but the best results are typical for mushrooms grown using a brewing waste. The addition of organic additives to the substrate positively affects the product quality $[14,15]$.

The introduction of brewing waste contributes to the increase of protein, fiber, fat and ash elements of fruit bodies. The production of the highest quality mushrooms was recorded under the conditions of an experiment carried out on a substrate prepared in the first flush in summer. It was experimentally proved that organic additives contribute to both the increase in yield and the nutritional value of mushrooms. Besides, the use of food additives - agricultural and processing wastes as part of a substrate for growing mushrooms provides for environmentally safe and economically efficient disposal of waste.

\section{Conclusion}

In modern conditions the environmental greening is particularly important. For example, alcohol and brewing waste amounts to 10 million tons per year, with only $10 \%$ to be processed. The main volume of brewing byproducts, up to $85 \%$, accounts for spent grain - brewing waste $[1,2,16,17]$. Many brewing enterprises try to avoid waste disposal by transferring the entire volume of by-products for secondary use, including for agriculture [2, 18-20]. Focusing on the secondary use of waste without damaging the environment and maximizing the economic effect predetermined the main directions of the study. The obtained experimental data confirmed the potential of the proposed method of waste utilization their use in mushroom farming as a biologically active substance that enriches a synthetic substrate and stimulates mushroom yield growth. The obtained data made it possible to conclude that the addition of brewing waste to the synthetic substrate (in comparison with other organic additives) allows achieving the maximum economic effect - to increase the yield and quality of mushrooms.

\section{References}

1. A. Soldatenko, N. Devochkina, M. Ivanova, Efficiency of the newest sterile substrate production technology for oyster cultivation, IOP Conference Series: Earth and Environmental Science, 395 (2019).

2. C. Pandin, R. Védie, T. Rousseau, D. Le Coq, S. Aymerich, R. Briandet, Biological Control, 127 
(2018).

3. N. Devochkina, R. Nurmetov, A. Razin, Economic assessment of the development potential of mushroom production in the Russian Federation, IOP Conference Series: Earth and Environmental Science, 395 (2019).

4. J.-M. Savoie, G. Mata, Mushroom Biotechnology Developments and Applications, 69, 91 (2016).

5. K. Zhichkin, V. Nosov, L. Zhichkina, Waste management system in the brewing industry, IOP Conference Series: Earth and Environmental Science, 337 (2019).

6. N. Devochkina, R. Nurmetov, O. Razin, The Analytical Review of the Development Prospects of the Protected Horticulture in the Russian Federation, Studies in Systems, Decision and Control, 282, (2020).

7. O. Arce-Cervantes, M. Saucedo-García, H. Leal Lara, R. Ramírez-Carrillo, F. Cruz-Sosa, O. Loera, Scientia Horticulturae, 192, 31 (2015).

8. E. G. Aleksandrova, V. A. Milyutkin, O. A. Blinova, Assessment of yield and quality of Agaricus bisporus champignon mushrooms, BIO Web of Conferences, 17 (2020).

9. Yu. N. Kudryashova, T. G. Lazareva, T. N. Makushina, Yu. V. Chernova, The organization of management accounting as a mechanism to improve the efficiency of agricultural enterprises, BIO Web of Conferences, 17 (2020).

10. V. Nosov, M. Tindova, K. Zhichkin, M. Mirgorodskaya, Application development for accidental pollution assessment on chemical manufacturers (pollution from chemical waste), IOP Conference Series: Earth and Environmental Science, 337 (2019).
11. E. M. Akhmetshin, A. V. Pavlyuk, A. S. Kokorev et al., Assessment of the economic security of the region (on the example of Chelyabinsk region), Journal of Applied Economic Sciences, 8, 62 (2018).

12. M. Ramos, N. Burgos, A. Barnard, G. Evans, J. Preece, M. Graz, A. C. Ruthes, A. Jiménez-Quero, A. Martínez-Abad, F. Vilaplana, Long Pham Ngoc, A. Brouwer, B. der Burg, M. C. Garrigós, A. Jiménez, Food Chemistry, 292, 15 (2019).

13. J. D. W. Adams, L. E. Frostick, Bioresource Technology, 99, 5 (2008).

14. A. Lakomiak, K. A. Zhichkin, Photovoltaics in horticulture as an opportunity to reduce operating costs. A case study in Poland, Journal of Physics: Conference Series, 1399 (2019).

15. T. Maseko, D. L. Callahan, F. R. Dunshea, A. Doronila, S. D. Kolev, Ken Ng, Food Chemistry, 141, 4 (2013).

16. M. M. Coello-Castillo, J. E. Sánchez, D. J. Royse, Bioresource Technology, 100, 19 (2009).

17. R. Altieri, A. Esposito, F. Parati, A. Lobianco, M. Pepi, International Biodeterioration \& Biodegradation, 63, 8 (2009).

18. S. R. Koyyalamudi, Sang-Chul Jeong, S. Manavalan, B. Vysetti, G. Pang, Journal of Food Composition and Analysis, 31, 1, (2013).

19. F. Parati, R. Altieri, A. Esposito, A. Lobianco, M. Pepi, L. Montesi, T. Nair, International Biodeterioration \& Biodegradation, 65 (2011).

20. M. V. A. Pontes, A. Patyshakuliyeva, H. Post, E. Jurak, K. Hildén, M. Altelaar, A. Heck, M. A. Kabel, R. P. de Vries, M. R. Mäkelä, Fungal Genetics and Biology, 112, 12-20 (2018). 